\title{
A scarcity of females may constrain population growth of threatened bird species: case notes from the Critically Endangered Raso Lark Alauda razae
}

\author{
M. DE L. BROOKE, T. P. FLOWER and M. C. MAINWARING
}

\begin{abstract}
Summary
Donald (2007) showed that the adult sex ratios of wild bird populations tended to be male-biased, and that this bias was stronger in threatened species than in those of least concern. Here we show that, in 2004, the world population of the Critically Endangered Raso Lark was 65 individuals, $70 \%$ of which were male (adult sex ratio 0.70 ). In 2008, the population numbered approximately 175 (including juveniles) and the adult sex ratio was 0.58 . Both ratios were significantly different from parity. All adult females were observed to be both paired and holding a territory. The observations therefore support Donald's (2007) suggestion that a shortage of females can be an important constraint on the growth of threatened bird populations, a constraint that needs attention in conservation planning.
\end{abstract}

\section{Introduction}

Donald (2007) collated information on the adult sex ratios (ASR) of wild bird populations and found that they tended to be male-biased, and that this bias was stronger in threatened species than in those of least concern. This highlighted the possibility that a shortage of females could be a significant constraint on the population growth rate and hence population recovery of threatened bird species. However, more data are required in order to assess the generality of this concept (Donald 2007).

Support for this idea is given credibility by situations where all, or nearly all, of the surviving members of a species have been male and we know of no cases relating to wild birds where the reverse has been true. For example, the Chatham Island Black Robin Petroica traversi was reduced to a population of five, of which one was a female (BirdLife International 2004). In 1994, the Norfolk Island Green Parrot Cyanoramphus cookii had a population of 32-37 of which four were females (Butchart et al. 2006). The Dusky Seaside Sparrow Ammodramus maritimus nigrescens became functionally extinct when reduced to six individuals, all male (Donald 2007).

While these examples refer to species reduced in number to less than 50 , where population recovery is dependent on a tiny number of females, it does not necessarily follow that the population growth of threatened species numbering hundreds or thousands is also constrained by the number of females, even if the ASR is male-biased. Population growth might, for example, be more dependent on the availability of suitable habitat and hence breeding territories (Komdeur 1992). Here, we present our findings from a study of the 'Critically Endangered' Raso Lark Alauda razae, a species whose fluctuating population has often fallen below 100 and has probably never exceeded 300 individuals since the species was described in 1898 (Donald and 
Brooke 2006). Raso Lark is known to have a male-biased ASR (Donald et al. 2005) and our findings suggest that population growth is highly likely to depend on the number of females.

\section{Methods}

The $7 \mathrm{~km}^{2}$ Cape Verdes island of Raso, to which the lark is endemic, has been visited annually by ornithologists for about two weeks in the months October-December from 2001 to 2008. It is a barren island where Raso Larks are easily detected. Since 2002, a proportion of the population, usually around $60 \%$ (M. de L. B. pers. obs), has been colour-ringed. Thanks to the open terrain, at least $98 \%$ of colour-ringed birds alive are detected in the two week visit (M. de L. B. pers. obs).

Since Raso Larks tolerate close approach, often $<10 \mathrm{~m}$, they are caught on the ground by placing a mist net, held taut between two observers, on top of them. There is no indication that this technique is biased towards catching one sex or the other. Once in the hand, birds can be confidently sexed using the marked sexual dimorphism in wing and bill size (Donald et al. 2005). Indeed a combination of the known sex of colour-ringed birds, the sex (by default) of any unringed birds paired to ringed birds, and the size of any remaining unringed, unpaired birds allows virtually all individuals to be sexed confidently.

When recently fledged, juveniles continue to be fed by their parents for at least two weeks (M. de L. B. pers. obs). Their plumage has a chestnut hue in comparison to the greyer adult plumage and the juvenile coverts, especially the uppertail coverts, have a broader pale edging. We presume that, like the congeneric Skylark Alauda arvensis (Cramp 1988), juvenile Raso Larks undergo a complete post-juvenile moult, but have no relevant observations. In sum, Raso Larks present exceptionally favourable opportunities for studies of the ASR of the entire world population, studies which are not hindered by such factors as cryptic behaviour or differential ranging behaviour of the two sexes (e.g. Suárez et al. 2009).

Nesting, which often follows rain (Donald et al. 2005), is unpredictable. Only during December 2004 and December 2008 were (a) most birds holding territories and (b) mapped in detail, taking advantage of the colour-ringed individually-known sexed birds.

\section{Results and Discussion}

In 2004, there were 19 post-juvenile females, all of which were paired to territory-holding males. For one pair, no nest was found. One or more nests were found for every one of the remaining 18 pairs. Besides these 19 females, one further female, a juvenile, was present. In addition to these 20 females, there were about 45 males on the island. Thus the world population was 65 and the ASR, expressed as proportion of males among post-juvenile birds, was 0.70 , significantly different from parity $\left(\chi_{1}^{2}=10.6, P=0.001\right)$.

In 2008, all 37 colour-ringed post-juvenile females were paired to territorial males, suggesting no post-juvenile females were unpaired and non-territorial. A further 27 unringed post-juvenile females were paired, yielding a total of 64 post-juvenile females. The nests of 17 were found. These females were paired to 17 unringed and 46 ringed males, one socially bigamous. In addition there were about 27 unpaired males (2O ringed and estimated seven unringed) and a minimum of 21 recently-fledged juveniles. The total island population in December 2008 was close to 175 and the ASR 0.58 , again significantly different from parity $\left(\chi_{1}^{2}=4.39, P<0.05\right)$.

As a result of the male-biased sex ratio, probably generated largely by differential mortality between the sexes (M. de L. B. unpubl. data), the number of territory-holding and potentially breeding females was only one-third of the number of Raso Larks on the island in these two periods of fieldwork. In neither 2004 nor 2008 were there post-juvenile females that were unpaired and without a territory. Thus there was no indication that the island was saturated with breeding pairs. The observations therefore support Donald's (2007) suggestion that a shortage of females can be an important constraint on the growth of threatened bird populations, a constraint that needs attention in conservation planning. 


\section{Acknowledgements}

We thank Julian Francis for supporting our fieldwork and Paul Donald for advice and comments.

\section{References}

BirdLife International (2004) Threatened birds of the world. Barcelona and Cambridge: Lynx Edicions and BirdLife International.

Butchart, S. H. M., Stattersfield, A. J. and Collar, N. J. (2006) How many bird extinctions have we prevented? Oryx 40: 266-278.

Cramp, S. ed. (1988) The birds of the Western Palearctic. Vol. 5. Oxford: Oxford University Press.

Donald, P. F. (2007) Adult sex ratios in wild bird populations. Ibis 149: 671-692.

Donald, P. F. and Brooke, M. de L. (2006) An unlikely survivor: the peculiar natural history of the Raso lark. Brit. Birds 99: 420-430.

Donald, P. F., Brooke, M. de L., Bolton, M. R., Taylor, R., Wells, C. E., Marlow, T. and Hille, S. M. (2005) Status of Raso Lark Alauda razae in 2003, with further notes on sex ratio, behaviour and conservation. Bird Conserv. Internatn. 15: 165-172.

Komdeur, J. (1992) Importance of habitat saturation and territory quality for evolution of cooperative breeding in the Seychelles warbler. Nature 358: 493-495.

Suárez, F., Garcia, J. T., Capriles, E., CaleroRiestra, M., Agirre, A., Justribó, J. H. and Garza, V. (2009) Sex-ratios of an endangered lark after controlling for a male-biased sampling. Ardeola 56: 113-118.

M. DE L. BROOKE*, T. P. FLOWER

Department of Zoology, University of Cambridge, Downing Street, Cambridge CB2 3EJ, UK.

M. C. MAINWARING

Lancaster Environment Centre, Lancaster University, Lancaster, LA1 $4 Y Q, U K$.

*Author for correspondence; e-mail:m.brooke@zoo.cam.ac.uk

Received 20 April 2009; revision accepted 5 November 2009;

Published online 26 March 2010 